\title{
MERCURY IN BIOLOGICAL MATERIALS
}

\author{
BY \\ S. L. TOMPSETT AND D. C. SMITH \\ From the Biochemical Laboratory, Northern General Hospital, Edinburgh
}

(RECEIVED FOR PUBLICATION JULY 12, 1958)

The present communication is concerned with the determination of mercury in biological materials and its normal excretion in humans.

As a preliminary step in the determination of mercury in biological materials, destruction of the organic matter is essential. Mercury has a high degree of volatility and hence precautions are necessary to prevent losses during this process. There have been many communications on this subject (cf. Sandell, 1950), but the simpler procedures are mostly applicable to urine only. Abbott and Johnson (1957) have described a relatively simple procedure for the determination of mercury in apples. The material is heated with a mixture of sulphuric and nitric acids in the presence of selenium in a special reflux apparatus. Oxidation is completed by the addition of hydrogen peroxide. This procedure has been found to be applicable not only to urine but to faeces and tissues. The hydrogen peroxide has been replaced by potassium permanganate, since a lower blank value can thus be obtained.

The most convenient method for the colorimetric determination of mercury is with dithizone using a reversion technique (cf. Irving, Risdon, and Andrew, 1949). Of the reversion techniques described, that using sodium thiosulphate in an acid medium (Abbott and Johnson, 1957) has been used. The use of a reversion technique involves two photometric measurements: (a) a solution containing unchanged dithizone and the metal dithizonate; and $(b)$ the previous solution after reversion, now containing the original unchanged dithizone and dithizone derived from the metal dithizonate. The difference between these two measurements is representative of the quantity of metal dithizonate present in (a). Assessment may be made by taking readings at the wavelength of maximum absorption of dithizone, i.e., $620 \mathrm{~m} \mu$, or of the metal dithizonate, i.e., $430 \mathrm{~m} \mu$ for mercury dithizonate. The differences are much greater at $620 \mathrm{~m} \mu$ than at $430 \mathrm{~m} \mu$. At $620 \mathrm{~m} \mu$ the differences $(b-a)$ are positive, while at $430 \mathrm{~m} \mu$ they are negative. It was therefore decided that it was preferable to carry out photometric measurements at $620 \mathrm{~m} \mu$ rather than at $430 \mathrm{~m} \mu$. The instrument used in the present investigation was the "unicam" diffraction grating spectrophotometer S.P. 350.

The method appears to be specific for mercury. The effect of copper and silver, two metals that occur in trace amounts in the human diet and might cause interference, has been examined. It has been found that these metals are not included in the final result. Non-interference from silver depends partly on the presence of excess of chloride ions, viz., hydroxylamine hydrochloride.

The following are the details of the method.

\section{Method}

Reagents.-The following are required :

(1) Concentrated sulphuric acid (Analar).

(2) Concentrated nitric acid (Analar).

(3) $5 \%(\mathrm{w} / \mathrm{v})$ potassium permanganate solution.

(4) $20 \% \quad(w / v)$ hydroxylamine hydrochloride solution.

(5) Freshly prepared $1.5 \% \quad(\mathrm{w} / \mathrm{v})$ sodium thiosulphate solution.

(6) Freshly prepared dithizone, $4 \mathrm{mg}$./litre in chloroform.

(7) $0.1 \mathrm{~N}$ hydrochloric acid.

(8) Selenium powder.

(9) Standard mercury solution, $1 \mathrm{mg}$. $\mathrm{Hg} / \mathrm{ml}$.$0.135 \mathrm{~g} . \mathrm{HgCl}_{2}$ in $100 \mathrm{ml}$. of $0.1 \mathrm{~N}$ hydrochloric acid.

Procedure for Urine.-A $500-\mathrm{ml}$. conical flask is fitted with a 12-in. air condenser, and above this is located a water-cooled reflux condenser. The equipment is of all-glass construction (Quickfit and Quartz, Ltd.). The two digestions described below are carried out in the apparatus with both condensers in situ.

Into the conical flask are measured $100 \mathrm{ml}$. of urine, $15 \mathrm{ml}$. of concentrated sulphuric acid, $5 \mathrm{ml}$. of nitric acid, and $0.1 \mathrm{~g}$. of selenium powder. The mixture is heated to boiling and maintained at this temperature for two hours. The mixture is cooled and then $10 \mathrm{ml}$. of $5 \%$ potassium permanganate solution added. The mixture is boiled for a further half hour. After cooling, the mixture is diluted to 


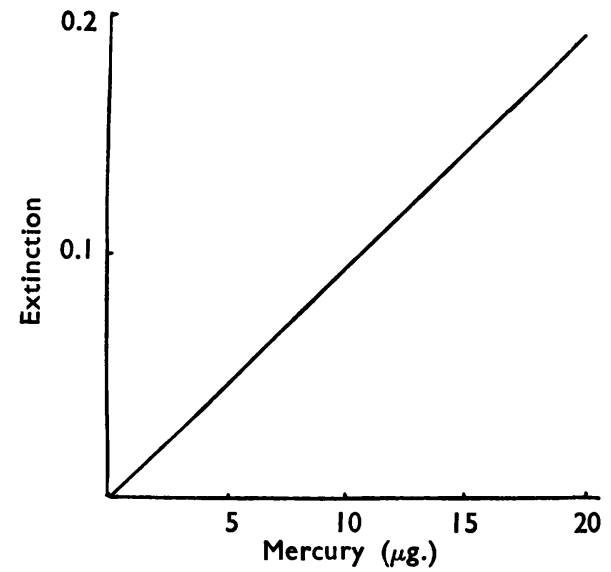

Fig. 1.-Determination of mercury by dithizone (reversion technique) in a "unicam" spectrophotometer S.P. $350-620 \mathrm{~m} \mu$.

$250 \mathrm{ml}$. with water and filtered through an acidwashed filter paper.

Into a $500 \mathrm{ml}$. separating funnel are introduced $125 \mathrm{ml}$. of filtrate and $20 \mathrm{ml}$. of hydroxylamine reagent. After mixing, $30 \mathrm{ml}$. of dithizone reagent is added and the whole shaken vigorously for two minutes. A sample of the chloroform extract is separated and the extinction read against chloroform at $620 \mathrm{~m} \mu$ (A). The complete chloroform extract is now transferred to a separating funnel containing $50 \mathrm{ml}$. of $0.1 \mathrm{~N}$ hydrochloric acid. Sodium thiosulphate solution, $2 \mathrm{ml}$., is added and the mixture shaken vigorously for two minutes to effect reversion. The chloroform solution is separated and the extinction read against chloroform at $620 \mathrm{~m} \mu$ (B).

The difference between readings $(B)$ and $(A)$ is a measure of the mercury content which can be evaluated by reference to standards.

Standardization.-Mercury, 5, 10, 15, and $20 \mu \mathrm{g}$., in the form of mercuric chloride in $100 \mathrm{ml}$. of water, is examined using the complete procedure described above. Within this range the calibration curve is a straight line running through the origin (Fig. 1).

Blanks.-The complete procedure is carried out using $100 \mathrm{ml}$. of water.

Procedure with Faeces.-Faeces are emulsified with water and made up to a convenient volume, e.g., a 24-hour output may be emulsified up to $250 \mathrm{ml}$. with water.

Faecal suspension, $20 \mathrm{ml}$., is diluted to $100 \mathrm{ml}$. with water and then examined as described for urine.

Procedure with Tissues.-Tissues may be examined in the same manner as faeces.

In the event of the sample containing more than $20 \mu \mathrm{g}$. of mercury, then a smaller aliquot than that suggested above should be used. This should be diluted to $125 \mathrm{ml}$. with blank solution before examination with dithizone.

The first dithizone extract may be conveniently divided into two equal parts, and one part only subjected to reversion. By reading (B) directly against (A), only one photometric reading is required.

\section{Results}

The Recovery of Mercury.-Mercury added to urine (5 to $40 \mu \mathrm{g}$. $/ 100 \mathrm{ml}$.) could be recovered with an accuracy of 91 to $98 \%$ (see Table I).

Mercury added to faecal suspension (10 to 40 $\mu \mathrm{g} . / 10 \mathrm{ml}$.) could be recovered with an accuracy of 88 to $98 \%$ (see Table I).

Reproducibility of Results.-The results shown in Table II and Table III indicate that reproducible results may be obtained within approximately $\pm 5 \%$.

\section{TABLE I}

RECOVERY OF MERCURY ADDED TO URINE (100 ML.) OR TO FAECAL SUSPENSION (20 ML.)

\begin{tabular}{l|c|c|c|c|c}
\hline Test & $\begin{array}{c}\text { Initial } \\
\text { No. }\end{array}$ & $\begin{array}{c}\text { Mercury } \\
\text { Added } \\
(\mu \mathrm{g} .)\end{array}$ & $\begin{array}{c}\text { Mercury } \\
\text { Deter- } \\
\text { mined }(\mu \mathrm{g} .)\end{array}$ & $\begin{array}{c}\text { Mercury } \\
\text { Recovered } \\
(\mu \mathrm{g} .)\end{array}$ & $\begin{array}{c}\% \\
\text { Recovered }\end{array}$ \\
\hline
\end{tabular}

\begin{tabular}{|c|c|c|c|c|c|}
\hline \multicolumn{6}{|c|}{ Urine } \\
\hline $\begin{array}{l}1 \\
2 \\
3 \\
4\end{array}$ & $\begin{array}{c}\text { Not detectable } \\
\text {," } \\
\text { ", } \\
\text {," } \\
\text {," } \\
\text {," }\end{array}$ & $\begin{array}{r}5 \\
10 \\
20 \\
30 \\
40 \\
5 \\
10 \\
20 \\
30 \\
40\end{array}$ & $\begin{array}{r}4 \cdot 5 \\
9 \cdot 5 \\
19 \cdot 0 \\
27 \cdot 5 \\
39 \cdot 0 \\
4 \cdot 5 \\
9 \cdot 5 \\
19 \cdot 0 \\
29 \cdot 5 \\
36 \cdot 5\end{array}$ & & $\begin{array}{l}90 \\
95 \\
95 \\
92 \\
98 \\
90 \\
95 \\
95 \\
98 \\
91\end{array}$ \\
\hline \multicolumn{6}{|c|}{ Faeces } \\
\hline $\begin{array}{l}1 \\
2 \\
3 \\
4 \\
5 \\
6 \\
7 \\
8\end{array}$ & $\begin{array}{l}9 \\
9 \\
9 \\
9 \\
6 \cdot 5 \\
6 \cdot 5 \\
6.5 \\
6.5\end{array}$ & $\begin{array}{l}10 \\
20 \\
30 \\
40 \\
10 \\
20 \\
30 \\
40\end{array}$ & $\begin{array}{l}18 \cdot 0 \\
28 \cdot 5 \\
36 \cdot 0 \\
46 \cdot 5 \\
15 \cdot 5 \\
24 \cdot 0 \\
34 \cdot 0 \\
45 \cdot 0\end{array}$ & $\begin{array}{r}9.0 \\
19 \cdot 5 \\
27 \\
37 \cdot 5 \\
9.0 \\
17 \cdot 5 \\
27 \cdot 5 \\
38.5\end{array}$ & $\begin{array}{l}90 \\
98 \\
90 \\
94 \\
90 \\
88 \\
92 \\
96\end{array}$ \\
\hline
\end{tabular}

TABLE II

REPRODUCIBILITY OF RESULTS IN FAECAL SUSPENSIONS (20 ML.)

\begin{tabular}{c|r|r|r|r}
\hline \multirow{2}{*}{ Sample } & \multicolumn{4}{|c}{ Micrograms Hg } \\
\cline { 2 - 4 } & Examination: & 1 & 2 & \multicolumn{1}{|c}{3} \\
\hline A & & $5 \cdot 0$ & $5 \cdot 5$ & $4 \cdot 5$ \\
C & & 9.0 & $9 \cdot 0$ & $8 \cdot 5$ \\
& & 12.0 & $12 \cdot 5$ & $11 \cdot 5$ \\
\hline
\end{tabular}

TABLE III

DETERMINATIONS OF MERCURY IN PRESENCE OF COPPER AND SILVER

\begin{tabular}{c|c}
\hline Mercury Used $(\mu \mathrm{g})$. & Mercury Determined $(\mu \mathrm{g})$. \\
\hline In presence of $100 \mu \mathrm{g}$. copper & $9 \cdot 5,10 \cdot 5$ \\
10 & $18 \cdot 5,20 \cdot 5$ \\
20 & $39 \cdot 0,41 \cdot 0$ \\
40 & $10 \cdot 0,10 \cdot 5$ \\
10 & $19 \cdot 5,20 \cdot 5$ \\
20 & $39 \cdot 0,40 \cdot 5$ \\
40 & \\
\hline
\end{tabular}


Copper and Silver.-Both copper and silver will under appropriate conditions form coloured dithizonates in acid solution. The results indicated in Table III show that there is no interference in the determination of mercury under the conditions described in this paper.

Normal Excretion.- - The mercury content of the urine from 24 humans without a history of abnormal exposure to mercury has been examined. Actually the content was so low as to be indeterminable by the present procedure. It was concluded that the daily excretion of mercury by the normal is less than $5 \mu \mathrm{g}$./day.

Faeces were examined in 24 cases without a history of abnormal exposure to mercury. All were collections over a period of four or five days. The mercury content was assessed at 55 to 180 (average 90) $\mu \mathrm{g}$./day (see Table IV).

TABLE IV

EXCRETION OF MERCURY IN URINE AND FAECES OF NORMAL SUBJECTS

\begin{tabular}{|c|c|c|c|}
\hline Specimen No. & Mercury ( $\mu \mathrm{g} . /$ day) & Specimen No. & Mercury ( $\mu \mathrm{g} . /$ day) \\
\hline \multicolumn{4}{|l|}{$\begin{array}{l}\text { Urine } \\
\qquad 24 \text { cases- }\end{array}$} \\
\hline \multicolumn{4}{|l|}{ Faeces } \\
\hline $\begin{array}{r}1 \\
2 \\
3 \\
4 \\
5 \\
6 \\
7 \\
8 \\
9 \\
10 \\
11 \\
12\end{array}$ & $\begin{array}{r}55 \\
95 \\
60 \\
180 \\
125 \\
75 \\
85 \\
140 \\
90 \\
60 \\
65 \\
95\end{array}$ & $\begin{array}{l}13 \\
14 \\
15 \\
16 \\
17 \\
18 \\
19 \\
20 \\
21 \\
22 \\
23 \\
24\end{array}$ & $\begin{array}{r}85 \\
125 \\
145 \\
75 \\
85 \\
80 \\
95 \\
65 \\
95 \\
70 \\
80 \\
75\end{array}$ \\
\hline
\end{tabular}

Mean: $90 \mu \mathrm{g} . / \mathrm{day}$

Standard deviation: $30 \cdot 2$

\section{Discussion}

Information regarding the normal excretion is essential if an assessment of abnormal exposure to the metal is to be made. Monier-Williams (1949) has summarized much of the available data.
Buckell, Hunter, Milton, and Perry (1946) have reported normal urinary excretion of mercury of 5 to $90 \mu \mathrm{g}$./day whereas the figures reported by Monier-Williams are of the order of $1 \mu \mathrm{g}$./day. The latter is indeterminable by the usual methods. The results reported in this paper are more in agreement with those of Monier-Williams.

According to Monier-Williams the normal intake of mercury is of the order of $20 \mu \mathrm{g}$./day. The analysis of individual foodstuffs is laborious, but one author (Tompsett, 1956) has indicated that a fair estimate of the alimentary intake of trace heavy metals may be made from an examination of faeces since urinary excretions and retentions are usually minute in comparison. From the results presented in this paper it would appear that the normal intake of mercury in the diet is of the order of $100 \mu \mathrm{g}$./day. Assuming that retentions are minimal it would appear from urinary examinations that absorption from the alimentary tract is minute.

An examination of urine does not necessarily present direct evidence of abnormal exposure to a heavy metal especially if exposure has ceased for some time. The use of chelating agents (cf. Leckie and Tompsett, 1958) could prove of value in such problems.

\section{Summary}

A method has been described for the determination of mercury in biological materials (urine, faeces, and tissues).

The normal excretion of mercury in urine was found to be less than $5 \mu \mathrm{g}$./day, and in faeces 55 to $180 \mu \mathrm{g}$. $\mathrm{Hg} /$ day.

\section{REFERENCES}

Abbott, D. C., and Johnson, E. I. (1957). Analyst, 82, 206. Buckell, M., Hunter, D., Milton, R., and Perry, K. M. A. (1946). Brit. J. industr. Med., 3, 55.

Irving, H., Risdon, E. J., and Andrew, G. (1949). J. chem. Soc. (Lond.), p. 537 .

Leckie, W. J. H., and Tompsett, S. L. (1958), Ouart, J. Med. $27,65$. Monier-Williams, G. W. (1949). Trace Elements in Food, p. 453. Chapman and Hall, London.

Sandell, E. B. (1950). Colorimetric Determination of Traces of Metals 2nd ed., p. 441. Interscience, New York.

Tompsett, S. L. (1956). Analyst, 81, 330. 